Paper

\title{
Tracing transforming honors tracks - Arts and sciences beyond borders
}

Peter Sonderen ${ }^{1 *}$, Jur Koksma²

1. Professor of Theory in the Arts, ArtEZ University of the Arts, Arnhem | Enschede | Zwolle, The Netherlands, P.Sonderen(at)artez.nl

2. Assistant Professor, Learning Researcher and Innovator, Radboudumc Health Academy, Radboud University Medical Center, Nijmegen, The Netherlands, Jur.Koksma(at)radboudumc.nl

* Corresponding author: P.Sonderen(at)artez.nl

Received: 1 February 2017; Accepted: 11 May 2017; Published: 12 May 2017

Keywords: Wunderkammer; borders; cross overs; science and art; transformative learning; self-directed learning

\begin{abstract}
In this paper we describe how honors students of an art university and a classical research university in the east of the Netherlands, came together to work on the development of new ecologies of art and science. We narrate a yearlong learning journey by highlighting two main projects, first a local Wunderkammer project and subsequently a joint research trip to New York, Boston and Cambridge for investigating similar initiatives across the Atlantic. While going beyond the borders of disciplines and institutions, in search of new terrain, students reframe their own field as well. By experimenting with the form of our honors tracks we hope to widen the horizon of young people and help them unleash their potential. Our meandering story describes how the honors track kept on changing form, by allowing students to claim radical ownership, and how this has taught us that such experiments can not only be carried out in a responsible manner, but may also create more powerful environments for learning across borders.
\end{abstract}

\section{Wonder}

Our story starts with the initiative of two teachers involved in the honors programs of the Radboud University and ArtEZ University of the Arts in two nearby cities in the Netherlands, to let their students meet someday. ${ }^{1}$ So it happened that a group of Radboud honors students was invited to pay a visit to the extraordinary underground lodgings of the theatre and dance departments of ArtEZ in Arnhem. This environment proved to be somewhat opposite of what they were used to. No school desks around but large, almost empty rooms instead, dark painted rooms that merely begged for human movement or other activities to 
take place, literally. Experiencing this spatial difference with their daily surroundings influenced their view on the arts. A lot of those Radboud students had no clue whatsoever of where and how, in general, art students learned and worked. The meeting proved to be fruitful: the honors students exchanged overall ideas and idiosyncrasies of their respective artistic and scientific disciplines, group photos were made and distributed, and hopes were expressed to continue, in whatever way, the encounter.

\section{Wonder-room}

In the meantime, the cultural organization of the Radboud University ('Cultuur op de Campus') contacted the Society of Arts, which is part of the Royal Netherlands Academy of Arts and Sciences (KNAW). Both parties approached the staff of the Radboud Honours Academy and the ArtEZ Honours Program. They were looking for opportunities to involve students in their activities to have them learn about the role of the arts within society. Their proposal was to involve both art and science students in a project that the Society of Arts had coined 'Wunderkammer': a 'wonder-room' or Cabinet of Curiosities. During a few meetings, with a special evening in the Amsterdam Trippenhuis, where the KNAW resides, the group formed itself and explored the idea of the Wunderkammer. ${ }^{2}$

The Wunderkammer, or to follow Julius von Schlosser's phrase 'Kunst- und Wunderkammer', ${ }^{3}$ was the place and space in which curiosities of the world were collected and displayed as from the $16^{\text {th }}$ century. These collections were organized in a way that did lack, to our modern eyes at least, any recognizable taxonomy. Works of art, wonders of nature, and all kinds of other curious objects and machines, were displayed in an unorderly and unusual manner. These Wunderkammers appear to us as pure products of the imagination, as a form of surrealism avant la lettre. What finally became clear in our collective musings on this phenomenon is that these collections did not differentiate at all between art and science as we do now. They were just mingled and not set apart; they were the result of wonder and admiration about all kinds of natural or artificial things, whatever their origin. Ever since the nineteenth century our museums have begun to leave this particular way of displaying behind. Science and art developed into separate realms and metaphysical entities. In the Netherlands, the extraordinary $18^{\text {th }}$ century Teylers Museum in Haarlem was one of the last established museums in which art and science would find a shared place. Scientific machines, minerals, stones and monsters, and drawings by Leonardo and Rafael found refuge in the same building.

\section{Family room}

All student participants agreed that the model of the Wunderkammer as a seemingly nonhierarchical collection of objects from different fields, could catalyze thinking about current and future relationships of science and art. $^{4}$ As such, their notion fitted the purpose of the Wunderkammer-project, which was to facilitate the exchange of ideas and actions between students working across the fields of art, science and the humanities. The expected result should ideally be a platform for joint experimentation and interdisciplinary thinking, pivoting around wonder. A place where science and art would be siblings. Since family members also have to meet from time to time to confirm their mutual affiliation, the Wunderkammer would serve as the family room for thinking together. The family room was not a fixed place but was an imaginative, immaterial, yet existing space that was founded on a reciprocal interest in these fields. The Wunderkammer group represented, in short, a wide variety of 
artistic, scientific and scholarly disciplines, including philosophy, medicine, physics, fine art, dance, theatre and graphic design.

\section{Wonder and wander}

We challenged the students to reconsider their own areas of expertise as well as their familiar ways of knowledge production, to broaden up their own perspectives and to give free rein to curiosity, serendipity and the workings of the imagination. We asked them to critically enquire their own and others' convictions, and try to reopen their view on art and science as from scratch. Obviously, this is not easy. We live in an age now where scientists at least in some fields - seem to claim and be given the final say about human nature, which fosters all kinds of preconceptions on both sides. ${ }^{5}$ The Wunderkammer provided a radically different, yet safe, environment to foster a state of open mind.

Admiration and wonder - looking as if everything you encounter is new - may lead to wandering about. ${ }^{6}$ At first, not knowing where to go, with no right direction being given, this turned out to be cumbersome for the students. They had to find out for themselves and let their curiosity speak. We, Academy and tutors of the honors program, only asked them to think and come up with something and to present that in a few months' time, in some public arena. What would science do when nothing is asked for, when no specific outcome was expected? What would art do when nothing is impossible beforehand? From our tutorial perspective, this was a crucial starting point because both art and science have come under severe political and societal surveillance, and are being curtailed constantly. Academic and artistic freedom is not self-evident nowadays. The arts are increasingly asked to be effective, not to say useful. A genuine opportunity for starting together from scratch would seem ideal, wouldn't it?

This was, to be honest, a bit optimistic. Students did take up the challenge, but had to get used, initially, to organizing their own meetings and having to come up with research ideas all by themselves. Self-direction is so alien to most mainstream educational surroundings, that even gifted students need some time to really grasp that it is up to them; even willing teachers have trouble getting this message across in a consistent and convincing way.

Evidently, we provided coaching, trying to help them as they were contemplating the values of artistic and scientific freedom. Employing freedom in thinking or acting is, after all, also something that involves learning or unlearning, but it must first linger (as an ideal) in one's mind before it can be strived for. To be confronted with emptiness - i.e. with no set question; no set field; no felt urgency; solely with the challenge to think and act from within their fields of knowledge - proved to be hard. Nevertheless, they became productive after considering these incentives. Students started to work, arranged meetings and tried to find out what their correspondences were and how they could find a general base for working together. What bound them together was the desire for getting in touch, to get closer, to find borders, and to cross them. It caused a kind of 'symphilosophizing' as Novalis, the German poet, would have called it. Novalis eye-witnessed the split of science and art at the start of the nineteenth century, and already saw the need to reconcile and not to diverge. ${ }^{7}$ 


\section{Wandering: an encounter}

While students were wandering and 'symphilosophizing' together and trying to find some shared themes, another initiative came to the fore. The famous harpist Lavinia Meijer was invited as an artist-in-residence at the Radboud University. Would it not be a good idea to seek a connection to this musician, who is a 'gormandizer' when it comes to working together with all kinds of musicians and music genres? And so it happened. She definitely challenged our Wunderkammer-students and functioned as a role model being a serious professional while having retained an 'ability to play'. This collaboration resulted in a special evening at the university, Wunderkammer meets Lavinia, ${ }^{8}$ in February 2016.

The program consisted of the preliminary results of the multidisciplinary research groups: 'Reversed Music', 'Cat Stories', 'Building Blocks: The return of the Cadavre Exquis', vocal improvisation and an 'Experiment on the Experience of Time', interspersed by improvised dance performances with Lavinia. ${ }^{9}$ These projects were not aimed at giving final answers or solutions, but they enriched questions and problems. Having been put into the frame of the performing arts some participants felt a little strange; an awkwardness perhaps related to having their regular knowledge and presentation environments being reframed. Others reacted differently by turning a 'happening' into a research opportunity. One of these scientific experiments, was placed and performed in the public arena itself and provided real-time research results. ${ }^{10}$ All student groups tried to take methods and methodologies out of their regular contexts and put them into new 'strange choreographies'. The most interesting aspect is that students from different disciplines and fields were willing to take risks in leaving their comfort zone. That was, to put it into a generally accepted language, the profit of the whole event: being together and balancing on new threads that were woven into uncertain entities. One of the students has put it this way: 'To break through stereotypes and paradigms one requires a lot of patience and willingness to give up one's own position.' 11

This newly made Wunderkammer was a display of interesting streams of thoughts and, sometimes, of objects like the 'Building Blocks'. ${ }^{12}$ The latter project was inspired by the Surrealist idea of the Cadavre Exquis, a method, as the group describes, '...in which the participants have an equal say, without having to compromise their respective talents: Inspired by this way of collective thinking we developed our own set of rules. Each person had to create an object, idea, proposal, etcetera to give to the next person. The second step was for this next person to further develop the given idea within one or two weeks and again give it to the next person. This would continue for a total of four sessions until all of the four participants had worked on it, resulting in sixteen separate and four final works. ${ }^{13}$

\section{Mind the Gap: Across the Atlantic}

After the presentations at the university and at the Honors Futures Conference in Utrecht in June 2016, the honors students took after their own business again. Connections were there and some students kept on seeing each other. Soon after we were offered the opportunity to apply for a subsidy for establishing new connections between the two institutes. We applied for subsidy for a study trip to the USA, the country that is known for its active honors communities. In a few months' time, we formed a (partly) new honors students group that would prepare the visits to interesting spots in New York, Boston and Cambridge. That is to say, once more we made the students responsible for an opportunity to explore other 
worlds. Also, we invited two more tutors representing the Radboud Honours Academy as a whole and the Radboud university medical center, respectively. All this led to an even broader group of 'specialists' than the Wunderkammer: twelve honors students from a different background, six from each institution formed the group. The variety of backgrounds ranged from music to medicine, from physics to fine art, and from dance to law. This variety was remarkable, at least to many of our American hosts. ${ }^{14}$

In the Wunderkammer project, students were challenged to overcome the problem of entering terrae incognitae without a structured assignment or dominant mode of working known from their own respective backgrounds. Now, with the new group we even wanted to take this one step further, and provide the students with the opportunity to develop their ownership, by taking a leading role in both the organization as well as in the programming of the trip.

The rationale behind this starts with the fact that in The Netherlands the natural sciences and the humanities together with the arts are already being divided during secondary education. Subsequently, most university students, starting at the early age of 17 or 18 years old, do not challenge the borders of their bachelor's programs, but direct their learning at what educational organizations want and get money for, i.e. for students to pass tests as quickly and smoothly as possible and graduate nominally. Assessment seems to direct their learning. This system has, however, a very unfortunate effect: when the program makes students start to wonder, most of the time they do not wonder about themselves or the world but about what the teacher wants them to do. Evidently, this is more so at a research university than at a university of the arts; still, following the teacher is the dominant educational format that we all know from school.

Thinking along these lines we started to realize that for students to really be given a chance to explore new territories, we would perhaps have to break with this default 'educational mode', just as with the Wunderkammer project, or even more so. In the next section we will elaborate on this link between border crossing and ownership of learning.

We therefore formed groups of three students and challenged them to take responsibility for one part of the trip's program (up to half a day). We organized preparatory meetings during which we, as a community of students and tutors, decided upon the final selection of program proposals. Some students even doubted whether they could get anything serious organized at all, given that they had only a few months' time. It was therefore very inspiring to finally see that they could take the lead, a few months later, in our visits to well-respected institutes like Harvard, MIT or The City College of New York. For them, as they told us, it was an experience they will never forget. One student received a nicely written personal e-mail from Noam Chomsky saying that he, unfortunately, could not meet them during that particular week, is a cherished witness and symbol of what may happen when you just reach out.

\section{Education models challenged by the trip}

Currently, educational innovation focuses on the development of so-called ' 21 st $C e n t u r y$ skills'. This is a catch-all term that seems to contain many higher order skills, not only those that are particularly related to the extant age like innovative technologies and digital 
literacy, but also skills that have been relevant since the dawn of mankind, like critical and creative thinking. The urgency however behind this focus is the fact that people feel that the ' $21^{\text {st }}$ century workplace' is changing so rapidly that it is very uncertain what our professional lives will look like the coming decades. Change will be our only constant, as the saying goes, and hence we know for sure that $21^{\text {st }}$ century professionals will need to be adaptive and keep on learning. That begs for them to constantly frame and reframe their own field of expertise and those of others.

At the start of the third millennium major authors in the field of self-directed learning (SDL) already said it would be likely that SDL would come to the fore because of an increasing societal demand for lifelong learning. ${ }^{15}$ For years SDL was associated with 'andragogy', not with a key set of skills we should start to acquire from a very young age, and onwards, particularly at the university level.

Even though self-direction and personal leadership are now at the heart of today's view on education and SDL is considered to be the key link between undergraduate education and continuing professional development, one may argue that change is slow when it comes down to giving students and professionals substantial freedom to develop such skills. The dominant paradigm is that of the discipline, and the prevailing educational format is still largely based on organizational demands and not that of the learner per se. Consequently, millions of students across the globe are still being spoon-fed.

This even holds for some honors programs, in particular for some faculty-based tracks that try to further specialization. These tracks do obviously serve a purpose, and may even be considered excellent in some sense, but they do not necessarily embody the idea that the learner him- or herself determines the quality of his or her personal and professional development. The Radboud Honours Academy's interdisciplinary programs, on the other hand, focus on the enrichment of the individual student by intentionally crossing borders of the natural sciences and the humanities. Even then, however, many parts of the honors program consist of traditional didactic formats. To really help students open up to new vistas we believe they need to go 'all-in' and therefore be given the chance to organize their own learning experience.

That is why we handed our students the task to organize their own program in the USA, but make it fit within the confines of the overall program and aims. But would this work? Wouldn't they first have to experience it before actually grasping it? It turned out that merely telling them our didactic, little schemes did not do the trick, and we did not expect that either. We knew beforehand that they had to live through it to see what it would imply for them personally. Experimenting with providing freedom is risky, but, within the context of this honors program which was all about venturing out, we wanted to take the challenge and risk. Could we ourselves have come up with an even 'better' program for the trip, making use of our own networks and affiliation? Probably. In that case we would, however, not have challenged the students to think about what they wanted, for themselves, and as a group. Even during the first meeting in New York, we noticed that students were still waiting for tutors to take the lead during conversations with our American partners. Only after we discussed everybody's expectations at length, sitting on some boulders in Central Park, they could break through the conventional operating mode. 
The students came up with several proposals, so we visited varied spots: the DIAP for instance, the Digital and Interdisciplinary Art Practice MFA program of the City College of New York, ${ }^{16}$ where we did a workshop which was proposed and organized by one of the ArtEZ students. The fact that we had this active role for our own students, made them not only prepare very well, but also take the lead during their part of the program, which many pointed out as something that they learned a lot from: 'My own workshop at the Central Square Theatre springs to mind immediately, because I could test my teaching competencies in a totally new setting. I realized I am a teacher in heart and soul.'

We went to the Hall of Science where we had talks with the staff and found out, among other things, that art was also present but, to our opinion, only serving an illustrative purpose, not as a force of its own. Eleven out of twelve students report that most crossovers we encountered were manifestations, actually, of one discipline 'serving' the other. We were present at a performance evening of the Judson Dance Theater in NYC, a famous place for experiments in performance. Students and tutors joined the collective dance moments actively and could experience the researching quality of such kinds of meetings and gatherings. The performances were not set up as a show but were open for questions, comments and physical participation. Here, a university student called it 'scientific': 'I didn't understand a lot of it, but it really felt like research, like experimenting.' Whereas an art student was wondering about the borders of art: 'Was this art? Half of the audience was on stage, copying the performer and creating the performance all together.' In Boston we had meetings at MIT and Harvard. At Harvard Kennedy School we visited a social psychology research group focused on the science of nudging. We found out that they did not invite artists or designers to help create the nudges they investigated. We did a design-thinking workshop, creating nudges on the spot, in small groups of both scientists and artists, leaving our hosts with astonishment after an hour, because of the quick and unexpected results by working in a different mode i.e. by tapping differently into our own, hidden creative resources.

With regard to us experimenting with ownership we saw different patterns. Given the age difference, 19 to 25 years, we of course knew some students would be further ahead in this regard. ${ }^{17}$ One of the younger students writes in her reflection on the trip: 'One of the things I remember best is sitting together in Central Park like a troop of monkeys on the rocks and talking about expectations. It definitely underscored the relevance of making everyone's expectations manifest. I didn't know they were so far apart.' She refers to one particular moment early on in the trip when the teachers decided to be more outspoken about what they expected, which is to show more leadership. A few of the students paradoxically replied to that: 'If you would have told us to do it, we would have done it.' This anecdote is just one in a row that demonstrate how students started to value process over outcome.

What we wanted is for the entire track to be a formative experience. For some it really seems to have opened their eyes: 'Art always seemed a luxury to me, like you would have the luxury not to be a farmer in our society. Now I have come to realize that it is part of being human.' The group dynamics played a big role in that, according to what another student says: 'The trip was not only about discovering what we want to do together, but also who we are together.' Whereas the reflections of the university students seem to show 
more of these 'formative' examples, the art students reflect more on the borders of their own discipline and are more precise in what they are doing differently now, after the trip: 'When I work on a project I often look at the scientific approach and try to eliminate 'style' or 'traditions' in the toolbox that has already been established.' This can also be quite fundamental: 'I have learned that the more relevant questions are actually asked outside the fine arts.'

\section{Conclusion: the sequel}

In retrospect we can conclude that giving free rein to students within an honors course is a tricky but fruitful enterprise, which is not easy because it contains a lot of uncertainties. Students had to enter the no-border-land of art and science, the teachers had to refrain from interfering. The latter position is not easy too because they are always imbued with responsibility and learning goals. By intentionally transforming the status quo, by altering the very forms of knowledge, of learning, of collaboration, of place and time, we provided space for new encounters. Students could adopt new perspectives, create new outlooks on themselves and on others, and on other domains. By recording all the meetings in NYC and Boston that the students had organized and by interviewing them and by finally asking them to write a critical reflection on the trip and the - still - on-going journey that they have themselves started, we are trying to follow these tracks of transformation. ${ }^{18}$ Some of the traces we report here, express our hopes that others will find inspiration in it.

As teachers we also became aware of our own transformed positions within the whole trajectory. Leaving authority behind when observing that things might go wrong is quite challenging. But what can be wrong when the outcome is that all these transformations will have a lifetime effect? This is probably the explanation why students gave us advice (when we finally had returned home) to not restrict bringing fields together to honors students only; every student should get this opportunity. We agree.

Some of the students who travelled to the USA have now formed a new community, only loosely connected to the institutions, and are gathering regularly in so-called 'Salo(o)ns', carrying on their investigations and hooking up to several other organizations and border crossing initiatives. The initiative has been recently baptized Scart up! During one of the gatherings we were being introduced as tutors to a couple of new members of this community. In response, we have said that we were no longer tutors, but would be grateful to be accepted as regular members of this interesting and promising ensemble. ${ }^{19}$ Teachers and students have become equals. Reframing roles and reframing ideas and domains is what honors should strive for.

\section{Acknowledgements}

We wish to thank our dear and inspiring colleagues Marijn de Langen, Marlies van Hak and Dalila Sehovic (ArtEZ University of the Arts), Charlotte Brand and Martijn Stevens, Ariane Vervoorn (Radboud University), Barbara Visser, Bart Haensel, Annelies ten Have (Society of Arts/KNAW) who all contributed to this journey. We wish to thank the Sirius Program for its (financial) support. Without the participating students, however, this text would have been impossible, thanks to them all. 


\section{References}

Brockett, R. G. (2000). Is it Time to Move On? Reflections on a Research Agenda for SelfDirected Learning in the $21^{\text {st }}$ Century. Adult Education Research Conference. http://newprairiepress.org/aerc/2000/roundtables/7

Grow, G. O. (1991). Teaching learners to be self-directed. Adult education quarterly 41(3), 125-149.

Koksma, J.J. (2014). Narrators of Neuromyth. In Coenen, C., Dijkstra, A., Fautz, C., Guivant, J., Konrad, K., Milburn, C., \& van Lente, H. (Eds.) Innovation and responsibility: engaging with new and emerging technologies, 149-163. Berlin: Akademische Verlagsgesellschaft.

Kuipers, S., Hillen, C., Sheffer, C., Kuijpers, S. (n.d. [2016]). Time (In)dependent Manipulation Experience. A practical experiment on the experience of time within the framework of the Wunderkammer Project of the Royal Dutch Academy of Arts. n.pl, n.d. http://www.ru.nl/publish/pages/793213/time_independant_manipulation_experience.pdf

Merriam, S. B. (2001). Andragogy and self-directed learning: Pillars of adult learning theory. New directions for adult and continuing education 89, 3-14.

Sonderen, P. (2013). Het Honours Programme Theorie en Onderzoek. Een stevige en inspirerende uitdaging voor kunststudenten [The Honors Program Theory and Research. A big and inspiring endeavor for art students]. Tijdschrift voor Hoger Onderwijs \& Management (TH\&MA) 1, 55-60.

Sonderen, P. \& De Langen, M. (2013). Van zelf spreekt niets [No thing is self evident]. In AzK, Art a/z Knowledge, 0-4. Arnhem: ArtEZ University of the Arts.

Sonderen, P. (2016). Tussen academies en academisch. Over onderzoek in het kunstonderwijs [Between academic and academics. On research in art education]. Tijdschrift voor Hoger Onderwijs \& Management (TH\&MA), 4, 24-29.

Sonderen, P. (2017a). Where theory and artistic practice meet: the art of oscillation (on Hemsterhuis, Novalis and now). In: Sonderen, P. \& De Langen, M. (Eds.), Theory Arts Practices, 18-69. Arnhem: ArtEZ Press.

Sonderen, P. (2017b). 'Of Research, Passion and Art'. Journal of Aesthetic Education 51(1), 54-68.

\section{Additional relevant webpages / other sources}

- $\quad$ www.knaw.nl/en/news/calendar/introduction-to-the-wunderkammer-project

- www.ru.nl/honoursacademy/

- www.artez.nl/en/study-programmes/honours-programme-theory-and-research 
- http://www.ru.nl/codc/english/events/wunderkammer/copy-review-results/

- Wunderkammer meets Lavinia AFTERMOVIE: https://www.youtube.com/watch?v=Cfe-UIEcOWk

\section{Notes}

${ }^{1}$ They were Marlies van Hak Ma, coordinator and tutor at the ArtEZ Honours Program, and dr. Martijn Stevens, tutor and program co-director at the Radboud Honours Academy; the meeting took place in the spring of 2015. ${ }^{2}$ https://www.knaw.nl/en/news/calendar/introduction-to-the-wunderkammer-project

${ }^{3} \mathrm{http} / / /$ digi.ub.uni-heidelberg.de/diglit/schlosser1908, retrieved 18/1/2017.

${ }^{4}$ Although many students were interested in the project, only a few could finally apply because of lack of time. The project was not only additional to their bachelor program but also to their honors program. Still about 10 students have started the project, and are still active; they have regular meetings ('Salons') and hook up with other initiatives on the border of arts and sciences (like Kunstlab).

${ }^{5}$ Think of the current 'neuro-hype' allowing something to be real only if it is made visible by brain imaging techniques (Cf. Koksma, 2014).

${ }^{6}$ Descartes saw admiration as the first passion that could not be reduced to another one and was therefore basic to scientific wonder.

${ }^{7} \mathrm{Cf}$. Sonderen, 2017a.

${ }^{8}$ http://www.ru.nl/codc/english/events/wunderkammer/copy-review-results/

${ }^{9}$ The evening was moderated by philosopher Cees Leijenhorst. Musicologist and musician Vincent Meelberg played double bass and was asked to reflect on the outcomes from a scientific perspective.

${ }^{10}$ See for details of the experiment Kuipers et. al., n.d. [2016]; its main question was if time had an objective basis. The results indicated that measurement and experience of time do not coincide.

${ }^{11} \mathrm{http} / / /$ www.ru.nl/codc/english/events/wunderkammer/copy-review-results/

${ }^{12}$ Building Blocks: http://www.ru.nl/codc/english/events/wunderkammer/copy-review-results/and http://www.ru.nl/codc/english/events/wunderkammer/copy-review-results/examples-building-blocks/

${ }^{13}$ See for examples: http://www.ru.nl/codc/english/events/wunderkammer/copy-review-results/.

${ }^{14}$ One of the students remarked in her reflections on the trip that she saw that our American hosts were impressed by this mere fact, which they called 'an accomplishment in itself.' With honors students from dance, political science, music theatre, European law, fine art, history, physics \& chemistry, graphic design, medicine, theatre education and public administration we were indeed an extraordinary mixed group. The university students were 19-21 years old and were in their second or third year of their bachelor's program. The art students were 21-25 years of age.

${ }^{15}$ Brockett, 2000; Merriam, 2001.

${ }^{16}$ https://www.ccny.cuny.edu/diap

${ }^{17}$ Grow, 1991.

${ }^{18}$ For this publication we have concentrated on the transformative aspects.

${ }^{19}$ Participants ArtEZ University of the Arts. Staff: dr. Peter Sonderen, Marijn de Langen, MA, Marlies van Hak, MA. Students: Léa Vinette, Carcom Sheffer, Nina Meijer, Michiel Terpelle, Chris Hillen, Cassandra Onck, Johanna Tengan, Laura Saumweber, Annelie Koning, Kaulane Huisman, Lyanne van den Berg. Participants Radboud University, Honours Academy. Staff: dr. Charlotte Brand, dr. Martijn Stevens, dr. Jur Koksma (Radboud UMC). Students: Emma Sonnemans, Lisa Dulfer, Stach Kuijpers, Stan Boschman, Stijn Kuipers, Victor Ellenbroek, Rick Geurts, Fabian Kok, Thieme Stap, Daniëlle Gijzen, Lisa van Lierop, Stach Kuijpers.

Participants Society of Arts (Akademie van Kunsten/KNAW). Barbara Visser, Bart Haensel, Annelies ten Have. Participant Cultuur op de Campus (Radboud University). Ariane Vervoorn. 